\title{
UNCITRAL Model Law on Cross Border Insolvency Sebagai Model Pengaturan Kepailitan Lintas Batas Indonesia dalam Integrasi Ekonomi ASEAN
}

\author{
Dicky Moallavi Asnil \\ Program Magister Ilmu Hukum Universitas Indonesia \\ dmoallavi@gmail.com
}

\begin{abstract}
The economic integration program between the members of Association of South East Asian Nations (ASEAN) and surrounding areas that trancends national borders and citizenship potentially creates the cross borders bankrupcy problems. The problem was born when the debtor undergoing bankruptcy process has assets abroad,where the bankruptcy proceedings are hampered by the laws of the country concerned. In adition, Indonesia and ASEAN do not yet a bankruptcy regulation that binds its member states in the settlement of this problems. UNCITRAL Model Law on Cross Border Insolvency with Guide to Enactment is a model of cross-border insolvency law made by The United Nations which aims to be a reference of the world countries in the business of modernization and harmonization of national bankruptcy law respectively. This article shows that UNCITRAL Model Law on Cross Border Insolvency with Guide to Enactment which adheres to this flexibility principle can be used as a solution to modernize and harmonize bankruptcy law of ASEAN countries, especially Indonesia.
\end{abstract}

Keywords: ASEAN Economic Integration Program; cross border insolvency; UNCITRAL Model Law on Cross Border Insolvency 


\begin{abstract}
Abstrak
Program integrasi ekonomi antar negara anggota Association of South East Asian Nations (ASEAN) dan sekitarnya yang melampaui batas-batas negara dan kewarganegaraan saat ini berpotensi melahirkan permasalahan kepailitan lintas batas. Permasalahan itu lahir pada saat debitor yang menjalani proses kepailitan di suatu negara memiliki aset di luar negeri, di mana proses kepailitan terhadap aset pailit itu terhambat oleh hukum yang berlaku di negara bersangkutan. Indonesia dan ASEAN sampai saat ini belum memiliki peraturan kepailitan yang mengikat negara anggotanya dalam penyelesaian permasalahan ini. UNCITRAL Model Law on Cross Border Insolvency with Guide to Enactment adalah sebuah model hukum kepailitan lintas batas yang dibuat oleh Persatuan Bangsa-Bangsa yang bertujuan untuk menjadi rujukan negara-negara dunia dalam usaha modernisasi dan harmonisasi hukum kepailitan nasional masing-masing. Hasil penelitian menunjukkan bahwa UNCITRAL Model Law on Cross Border Insolvency with Guide to Enactment yang menganut prinsip fleksibilitas dapat dijadikan solusi dalam upaya melakukan modernisasi dan harmonisasi hukum kepailitan negara-negara ASEAN, khususnya Indonesia.
\end{abstract}

Kata Kunci: Program Integrasi Ekonomi ASEAN; kepailitan lintas batas; UNCITRAL Model Law on Cross Border Insolvency

\title{
A. Pendahuluan
}

Artikel ini membahas permasalahan kepailitan lintas batas negara. Di Indonesia, hukum kepailitan yang tertuang dalam Undang-Undang Nomor 37 Tahun 2004 tentang Kepailitan dan Penundaaan Kewajiban Pembayaran Utang (UU Kepailitan) belum mengatur kepailitan lintas batas, baik mengenai mekanisme maupun prosedurnya. Padahal, dalam perdagangan internasional dan terlebih integrasi ekonomi kawasan seperti ASEAN, persoalan hukum lintas batas negara termasuk dalam hal kepailitan sangat mungkin terjadi, sehingga membutuhkan aturan hukum yang jelas. Dengan membahas aturan kepailitan lintas batas dalam UNCITRAL Model Law on Cross Border Insolvency with Guide to Enactment, artikel ini mengajukannya sebagai model hukum yang bisa diakomodasi dalam hukum kepailitan Indonesia. 
Kepailitan sebagaimana dijelaskan dalam UU Kepailitan adalah sita umum atas semua kekayaan debitor pailit yang pengurusan dan pemberesannya dilakukan oleh kurator di bawah pengawasan Hakim Pengawas. ${ }^{1}$ Kepailitan merupakan suatu proses di mana debitor yang mempunyai kesulitan keuangan untuk membayar utangnya dinyatakan pailit oleh pengadilan, dalam hal ini adalah pengadilan niaga, dikarenakan debitor tersebut tidak dapat membayar utangnya. Harta debitor dapat dibagikan kepada para kreditor sesuai dengan peraturan perundangan yang berlaku. Kepailitan pada hakikatnya adalah melindungi kepentingan kreditor dan debitor. Bagi kreditor, kepailitan melindungi hak-hak kreditor dengan berlakunya asas jaminan. Kepailitan juga akan menjamin tentang pembagian harta kekayaan debitor di antara para kreditornya. ${ }^{2}$

Terintegrasinya perekonomian dunia telah membawa dampak peningkatan kegiatan perdagangan antar pelaku bisnis yang memiliki kewarganegaraan yang berbeda. Krisis ekonomi yang melanda Indonesia pada tahun 1997 telah meruntuhkan pondasi perekonomian nasional. Untuk mengatasi krisis tersebut salah satu upaya pemerintah adalah dengan meningkatkan jumlah investasi di Indonesia. Investasi ini diprioritaskan pada jenis investasi berdasarkan ekuitas (equity based investment) seperti penanaman modal asing dalam bentuk foreign direct investment (investasi langsung) dan investasi melalui pasar modal dalam bentuk portofolio investment (investasi portofolio). ${ }^{3}$ Kegiatan perniagaan asing ini kemudian meniadakan batas-batas negara. Konsekuensi yang tidak dapat dihindari sebagai akibat dari perkembangan transaksi bisnis internasional dan ekspansi perusahaan multinasional adalah kepailitan lintas batas (cross border bankruptcy). Kepailitan lintas batas timbul bilamana pelaku usaha yang menjalani proses kepailitan di suatu negara mempunyai aset yang berada di beberapa negara. Tidak adanya keseragaman atau harmonisasi hukum

1 Pasal 1 ayat (1) UU Kepailitan.

2 Siti Anisah, Perlindungan Kepentingan Kreditor dan Debitor dalam Hukum Kepailitan Indonesia (Yogyakarta: Total Media, 2008), hlm. 226.

3 Bagus Sujatmiko dan Nyulistiowati Suryanti, "Perlindungan Hukum bagi Investor pada Perusahaan Terbuka yang Dinyatakan Pailit Ditinjau dari Hukum Kepailitan”, Bina Mulia Hukum, 2, 1 (2017), hlm. 16. 
kepailitan (peraturan perundang-undangan) di antara negara-negara di dunia terhadap putusan pailit yang diajukan di suatu negara terhadap budel pailit yang berada di negara lain, menimbulkan masalah yang serius dan perlu diupayakan solusinya. ${ }^{4}$

Menurut Ketua Umum Asosiasi Kurator dan Pengurus Indonesia Ricardo Simanjuntak, dalam berbisnis pengusaha tidak selalu beruntung. Kadang kala ada pengusaha yang perusahaannya harus dipailitkan. Ketika itulah persoalan tentang wilayah yurisdiksi pengadilan dan eksekusi terhadap putusan pailit tersebut lahir. Setiap negara memiliki wilayah yurisdiksinya masing-masing yang kemudian menjadi halangan bagi pengurusan perkara maupun eksekusi putusan pengadilan terhadap harta atau aset yang berada di negara lain. Secara hukum, putusan kepailitan Indonesia tidak berlaku di luar negeri. Akibatnya, kurator Indonesia kesulitan mengurus boedel pailit. Begitu pula sebaliknya, kurator luar negeri tidak dapat menyita aset debitor luar negeri yang ada di Indonesia. ${ }^{5}$

ASEAN Free Trade Area (AFTA) adalah bentuk integrasi ekonomi lintas negara berkaitan dengan perdagangan bebas antar negaranegara anggota ASEAN dan atau negara lainnya yang telah disepakati bersama. Dengan AFTA, perusahaan asing akan lebih mudah melakukan kegiatan ekonominya di Indonesia, begitu juga dengan perusahaan Indonesia. Persaingan yang semakin ketat dalam mencari keuntungan dalam perkembangannya bisa menimbulkan konflik, perselisihan atau sengketa bisnis, maka dari itu diperlukan adanya pengaturan hukum yang menaungi. ${ }^{6}$ Saat ini Indonesia sebagai salah satu anggota ASEAN belum memiliki UU yang mengakomodasi permasalahan kepalitan lintas batas, baik mengenai mekanisme maupun prosedurnya. UU Kepailitan yang ada saat ini hanya memi-

4 Syamsudin M. Sinaga, Hukum Kepailitan Indonesia (Jakarta: Tatanusa, 2012), hlm. 171.

5 Ricardo Simanjuntak, "Digagas Aturan Cross-Border Insolvency”, http:/ / www.hukumonline.com/berita/baca/lt51f366e338725/ digagas--aturanicross-border-insolvency-i, 27/07/2017, diakses 22/10/2017.

6 Rahardjo Jamtomo, Sub Wilayah Ekonomi ASEAN dan Kawasan Perdagangan Bebas (AFTA) (Jakarta: Sekretariat Nasional ASEAN Departemen Luar Negeri, 1996), hlm. 187. 
liki tiga pasal yang mengatur kepailitan lintas batas, dan karenanya belum cukup. ${ }^{7}$

Sebagai contoh kasus, pada tahun 2002 Pengadilan Negeri Niaga Jakarta Pusat mengeluarkan Putusan No. 30/PAILIT/2002/ PN.NIAGA $/ J K T / \mathrm{PST}^{8}$ atas perkara sengketa antara Ny. Nyoman Soerabratha dan Ir. Marcus Pramono S sebagai pemohon pailit melawan pihak termohon The Ortrich Meat \& Marketing Co. (Australia) Ltd, yakni perusahaan multinasional dari Australia yang menjalankan kegiatan usahanya di wilayah Asia termasuk di Indonesia. Pengadilan memutuskan tidak menerima permohonan pailit tersebut karena perusahaan multinasional tersebut tidak terbukti berkedudukan di Indonesia dan tidak memiliki kantor perwakilan yang sesuai dengan peraturan Perusahaan dan Penanaman Modal Asing di Indonesia. ${ }^{9}$ Permasalahan timbul saat prinsip keadilan dan kepastian hukum tidak dapat terwujud oleh putusan tersebut. Perusahaan yang berkedudukan atau memiliki aset di luar wilayah Indonesia tidak dapat dieksekusi hartanya atau bahkan ada perdebatan dalam memutuskan yurisdiksi berkaitan dengan kompetensi relatifnya.

Dalam kaitannya dengan permasalahan kepailitan lintas batas, Persatuan Bangsa-Bangsa (PBB) melalui United Nation Comission on International Trade Law (UNCITRAL) yang merupakan sebuah komisi di bidang hukum perdagangan internasional, ${ }^{10}$ sebenarnya telah membentuk sebuah model atau contoh aturan hukum bernama Model Law on Cross-Border Insolvency with Guide to Enactment yang sifatnya tidak mengikat namun dapat menjadi acuan dan panduan bagi negaranegara yang mengalami permasalahan kepailitan lintas batas. Dalam Model Law ini dimuat antara lain: penerimaaan kurator dari negara

7 Sinaga, Hukum Kepailitan Indonesia, hlm. 172; C.P.F.Luhulima, Seperempat Abad ASEAN (Jakarta: Proyek Kerjasama Antar Negara ASEAN, Sekretariat Nasional ASEAN, Departemen Luar Negeri, 1994), hlm. 72.

8 Pengadilan Niaga pada Pengadilan Negeri Jakarta Pusat, Putusan Nomor 30/Pailit/2002/PN.Niaga/Jkt/Pst, hlm. 10-11.

9 A. Riris Murdani, "Pertimbangan HakimyangTidak Menerima Permohonan Pailit terhadap Perusahaan Multinasional di Indonesia (Analisis Putusan Nomor 30/Pailit/2002/PN.Niaga/Jkt.Pst" (Skripsi, UIN Sunan Kalijaga, Yogyakarta, 2016), hlm. 7.

10 Http://www.uncitral.org/uncitral/en/about_us.html, diakses 22/10/2017. 
lain di pengadilan; penerimaan putusan kepailitan asing yang patut diakui beserta akibat hukumnya, dan; peletakan dasar kerjasama dan koordinasi antar pengadilan, antara para kurator dan pengurus, atau kerjasama melalui sekretariat UNCITRAL.

Sarana kepailitan di atas tentunya memberikan kemudahan pada suatu negara dalam mendapat pengakuan dan melaksanakan putusan pailit oleh pengadilan niaga negara lain yang telah mengadopsi Model Law ini. Tapi sayangnya Indonesia dan banyak negara lain di ASEAN belum melakukan hal tersebut. Dalam artikel ini, UNCITRAL Model Law akan dibahas materinya terutama berkenaan dengan kepailitan lintas batas, untuk kemudian dikaji kemungkinanya diadopsi dalam hukum Indonesia dan negara-negara anggota ASEAN dalam menghadapi integrasi ekonomi ASEAN.

\section{B. Kemungkinan UNCITRAL Model Law on Cross-Border Insolvency with Guide to Enactment Diadopsi di Indonesia dalam Integrasi Ekonomi ASEAN}

Secara universal, hukum kepailitan diperuntukkan bagi debitor yang tidak mampu membayar atau dengan lain perkataan berada dalam keadaan kondisi keuangan yang tidak sehat (insolvent). Dengan adanya peraturan kepailitan ini, maka secara das sollen negara mencoba memberikan jalan keluar bagi debitor yang sedang mengalami kesulitan keuangan (financial distress) agar dapat melakukan pelunasan utang meskipun tidak seeara penuh. ${ }^{11}$ Sebagaimana diketahui bahwa setiap transaksi bisnis yang dilakukan antara pelaku usaha dengan pelaku usaha lain yang berbeda warga negara tidak terlepas dari pengaturan oleh negara. Oleh karena itu segala ketentuan yang mengatur tentang transaksi bisnis yang dilakukan oleh pelaku usaha harus berpedoman pada ketentuan hukum yang ada di negara bersangkutan. Seringkali praktik-praktik mengenai transaksi bisnis internasional di negara pelaku usaha dengan negara pelaku usaha lainnya tidak sa-

11 Freddy Josep, "Perlukah Revisi Undang-undang Kepailitan? (Suatu Kajian Mengenai Imbas Kasus Manulife dan Prudential)", Jurnal Hukum dan Pembangunan, 34, 1 (2004), hlm. 67. 
$\mathrm{ma}^{12}$

Pertanyaan kemudian timbul sehubungan dengan prinsip yang dianut oleh kebanyakan sistem hukum di banyak negara bahwa putusan pengadilan mengenai suatu perkara, lebih-lebih lagi dalam hal perkara itu adalah perkara kepailitan, tidak dapat dieksekusi di suatu negara. Penolakan eksekusi tehadap putusan asing itu tekait erat dengan konsep kedaulatan negara. Landasan hukumnya adalah Pasal 264 ayat (1) UU Kepailitan, yang esensinya adalah memberlakukan hukum acara perdata pada pengadilan niaga. Sementara itu hukum acara perdata yang berlaku di Indonesia, yaitu Pasal 436 Regelement op de Burgerlijke van Justitie (atau yang selanjutnya disebut Rv), secara tegas menentukan bahwa putusan pengadilan asing tidak dapat diakui dan tidak dapat dieksekusi oleh pengadilan Indonesia. ${ }^{13}$

UNCITRAL Model Law on Cross-Border Insolvency with Guide to Enactment adalah suatu model hukum yang dirancang untuk mengatasi permasalahan kepailitan lintas batas yang banyak terjadi di dunia dan disahkan pada tahun 1997. Model Law ini juga berfokus pada otorisasi dan mendorong kerja sama dan koordinasi antara yurisdiksi, harmonisasi undang-undang kepailitan substantif negaranegara dunia, dan menghormati perbedaan antara undang-undang nasional. ${ }^{14}$ Model Law ini secara umum memiliki lima tujuan yang disebutkan dalam pembukaan UNCITRAL Model Law on Cross-Border Insolvency with Guide to Enactment, yaitu:

1. Cooperation between the courts and other competent authorities of this State and foreign States involved in cases of cross-border insolvency (kerjasama antara pengadilan dan pejabat negara lain yang berwenang dan negara-negara asing ini terlibat dalam kasus-kasus kebangkrutan lintas batas).

2. Greater legal certainty for trade and investment (kepastian hukum

12 Hikmahanto Juwana, "Transaksi Bisnis Internasional dalam Kaitannya dengan Peradilan Niaga”, Jurnal Hukum dan Pembangunan, 31, 3 (2001), hlm. 225.

13 Hikmahanto Juwana, sebagaimana dikutip Sutan Remy Sjahdeini, Hukum Kepailitan (Jakarta: Pustaka Utama Grafiti, 2002), hlm. 474.

14 Http://www.uncitral.org/uncitral/en/about_us.html, diakses pada $8 / 11 / 2017$. 
yang lebih baik untuk perdagangan dan investasi).

3. Fair and efficient administration of cross-border insolvencies that protects the interests of all creditors and other interested persons, including the debtor (administrasi insolvensi lintas batas yang adil dan efisien yang melindungi kepentingan semua kreditor dan orang-orang yang berkepentingan lainnya, termasuk debitor).

4. Protection and maximization of the value of the debtor's assets (perlindungan dan maksimalisasi nilai aset debitor).

5. Facilitation of the rescue of financially troubled businesses, thereby protecting investment and preserving employment (memfasilitasi penyelamatan bisnis/ usaha yang bermasalah secara finansial, sehingga melindungi investasi dan melestarikan ketenagakerjaan). ${ }^{15}$

Untuk mengetahui apakah Model Law ini dapat diadopsi dalam hukum kepailitan Indonesia, penulis akan menjabarkan isi pokok dari UNCITRAL Model Law on Cross Border Insolvency With Guide to Enactment sebagai berikut:

\section{Pengakuan Proses Kepailitan Asing}

Dalam Model Law ini, perwakilan dari proses pengadilan kepailitan asing (kurator/pengurus asing) dapat mengajukan permohonan kepada pengadilan di negara lain untuk mengakui proses dan putusan pengadilan pailit di mana ia ditunjuk. Hal ini dijelaskan dalam Bab III Pasal 15 ayat (1) UNCITRAL Model Law on Cross-Border Insolvency with Guide to Enactment tentang Penerapan Pengakuan Proses Pengadilan Asing (Application for Recognittion for Foreign Proceeding) yang menyatakan bahwa "A foreign representative may apply to the court for recognition of the foreign proceeding in which the foreign representative has been appointed" (perwakilan asing dapat mengajukan permohonan ke pengadilan untuk mendapatkan pengakuan atas proses luar negeri dimana perwakilan asing tersebut ditunjuk).

Permohonan pengakuan terhadap proses dan putusan pailit asing ini harus memenuhi syarat-syarat yang memberikan kepastian

15 Preambule UNCITRAL Model Law on Cross-Border Insolvency with Guide to Enactment. 
dan kejelasan atas proses hukum asing yang berlangsung. Persyaratan ini menjadi bahan pertimbangan hakim yang menerima permohonan untuk kemudian menerima atau menolak sebuah permohonan pengakuan putusan pailit pengadilan asing. Persyaratan tersebut adalah:

a. Salinan resmi putusan pengadilan dan penunjukan perwakilan (kurator) asing.

b. Surat keterangan yang menjelaskan tentang proses pengadilan dan penunjukan perwakilannya (kurator/pengurus)

c. Jika 2 bukti di atas tidak ada, dapat menyertakan bukti lain yang dapat diterima dan diakui oleh perngadilan yang bersangkutan. ${ }^{16}$

Permohonan pengakuan ini juga harus menyertakan surat keterangan yang menjelaskan dan mengidentifikasi seluruh proses kepailitan yang diterjemahkan kedalam bahasa negara yang bersangkutan. Dalam aturan lanjutannya, pengadilan di suatu negara berhak untuk menolak permohonan pengakuan terhadap proses pengadilan asing jika tidak sesuai atau bertentangan dengan hukum nasional yang berlaku di negara tersebut.

Sejak saat permohonan pengakuan sampai dengan permohonan tersebut diputuskan, pada kondisi mendesak dan sangat dibutukan pengadilan suatu negara dapat meminta perwakilan asing tersebut untuk melindungi aset atau kepentingan debitor untuk sementara waktu. Hal ini dapat dilakukan jika berada dalam kondisi di mana aset debitor dikarenakan sifatnya atau keadaan mendesak lain tidak tahan lama atau dalam keadaan yang membahayakan dan merugikan pihak-pihak yang bersangkutan. Aturan ini dijelaskan pada BAB III Pasal 19 ayat (1) UNCITRAL Model Law on Cross-Border Insolvency with Guide to Enactment.

\section{Yurisdiksi}

Menurut sistem HPI Indonesia, putusan kepailitan memakai prinsip teritorialitas sehingga suatu keputusan pailit yang diucapkan di

16 Preambule UNCITRAL Model Law on Cross-Border Insolvency with Guide to Enactment. 
luar negeri tidak mempunyai akibat hukum di dalam negeri. Oleh karena itu, dengan dianutnya prinsip ini maka seorang yang sudah dinyatakan pailit di luar negeri, tidak dapat dinyatakan pailit lagi di Indonesia. Hal ini juga berarti bahwa putusan kepailitan yang telah diucapkan di Indonesia, hanya mempunyai akibat terhadap bendabenda yang terdapat di dalam wilayah negara sendiri. ${ }^{17}$

Putusan hakim dari negara tertentu hanya dapat dilaksanakan di dalam wilayah negara itu sendiri dan tidak dapat dilaksanakan di negara lain. Di Indonesia sendiri putusan hakim asing tidak dapat langsung dilaksanakan di dalam wilayah Republik Indonesia, terutama putusan hakim asing yang bersifat condemnatoir (penghukuman). Hal tersebut juga berdampak bagi putusan pailit hakim Indonesia yang tidak dapat mengeksekusi harta debitor pailit yang berada di luar negeri. ${ }^{18}$

Dalam pasal 3 ayat (7) UU Kepailitan disebutkan bahwa "dalam hal debitur tidak berkedudukan di wilayah negara Republik Indonesia (RI) tetapi menjalankan profesi atau usahanya di wilayah negara RI, pengadilan yang berwenang memutuskan adalah pengadilan yang daerah hukumnya meliputi tempat kedudukan atau kantor pusat debitor menjalankan profesi atau usahanya di wilayah negara RI"19. Kemudian timbul pertanyaan bagaimana jika debitor tidak melakukan profesi atau usahanya dan atau sama sekali tidak memiliki aset di wilayah Indonesia? Untuk menjawab pertanyaan tersebut, pada Bab I Pasal 2 UNCITRAL Model Law on Cross-Border Insolvency with Guide to Enactment diperkenalkan istilah foreign main proceeding atau proses persidangan utama asing, yaitu forum pengadilan yang melaksanakan proses pengajuan permohonan pernyataan pailit hingga eksekusi aset pailit. Forum pengadilan ini ditentukan oleh lokasi utama atau pusat kegiatan ekonomi dan letak mayoritas aset debitor. Pengadilan antar negara yang berkepentingan akan melakukan koordinasi un-

17 Laura Hardjaloka, "Kepailitan Lintas Batas Perspektif Hukum Internasional dan Perbandingannya dengan Instrumen Nasional di Beberapa Negara”, Yuridika, 30, 3 (2015), hlm. 487.

18 Hardjaloka, "Kepailitan Lintas Batas", hlm. 489.

19 Pasal 3 ayat (7) UU Nomor 37 Tahun 2004. 
tuk kemudian menunjuk pengadilan yang akan mengawasi proses tersebut. ${ }^{20}$

Dalam poin ke 81 guide to enactment yang memberikan penjelasan tentang Pasal 4 Model Law dijelaskan bahwa pengadilan yang berwenang dalam kepailitan lintas batas negara dengan tidak membatasi yurisdiksi dari pengadilan lain atas permintaan dari perwakilan asing. ${ }^{21}$ Kemudian dijelaskan pula bahwa pengadilan tidak boleh menolak untuk melakukan tindakan hukum kecuali tindakan tersebut bertentangan dengan ketertiban umum dari negara yang bersangkutan. Hal ini dijelaskan pada Pasal 6 Bab I Model Law yang berbunyi "Nothing in this Law prevents the court from refusing to take an action governed by this Law if the action would be manifestly contrary to the public policy of this State". ${ }^{22}$

Dalam pelaksanaannya, pengadilan di sebuah negara dapat melakukan eksekusi terhadap aset debitor pailit yang berada di negaranya walaupun telah mengakui proses pengadilan asing. Model law ini tidak kemudian menghilangkan kewenangan untuk melakukan eksekusi terhadap aset-aset debitor yang ada di negara tersebut. Tujuan dari ketentuan ini adalah untuk mendorong keputusan terkoordinasi yang paling sesuai untuk mencapai tujuan kedua proses, misalnya memaksimalkan nilai aset debitor atau restrukturisasi perusahaan yang paling menguntungkan. ${ }^{23}$

Penentuan foreign mainproceeding dan foreign preceeding ini dapat menjawab pertanyaan yang selalu timbul dalam proses kepailitan lintas batas tentang pengadilan yang berwenang melaksanakan dan mengawasi proses kepailitan tersebut. Dengan demikian dapat mempermudah kreditor maupun debitor untuk menentukan pengadilan negara mana yang akan diajkuan permohonan pernyataan pailit dan

20 Chapter I article 2 UNCITRAL Model Law on Cross-Border Insolvency with Guide to Enactment.

21 Point 81 Part Two UNCITRAL Model Law on Cross-Border Insolvency with Guide to Enactment.

22 Chapter I article 6 UNCITRAL Model Law on Cross-Border Insolvency with Guide to Enactment.

23 Chapter V Article 28 UNCITRAL Model Law on Cross-Border Insolvency with Guide to Enactment. 
yang akan mengawasi proses kepailitan itu sendiri.

\section{Kerjasama antara Pengadilan Nasional dengan Pengadilan dan Perwakilan Asing}

Pada praktiknya, pengadilan di negara-negara yang sudah menyepakati perjanjian kepailitan lintas batas, baik bilateral maupun multilateral bersifat regional agreement dan meratifikasi Model Law ini, Law ini harus dengan maksimal melakukan kerjasama dan komunikasi dengan pengadilan atau perwakilan asing baik secara langsung maupun melalui pihak pelaksana putusan (kurator/pengurus asing). Hal ini dijelaskan pada Pasal 26 ayat (1) dan (2) UNCITRAL Model Law on Cross-Border Insolvency with Guide to Enactment tentang Kerjasama Pengadilan dengan Pengadilan atau Perwakilan Asing yaitu:

a. In matters referred to in article 1, a (insert the title of a person or body administering a reorganization or liquidation under the law of the enacting State) shall, in the exercise of its functions and subject to the supervision of the court, cooperate to the maximum extent possible with foreign courts or foreign representatives. ${ }^{24}$ (Dalam hal yang disebutkan pada Pasal 1, kurator atau pengurus dalam menjalankan tugasnya tunduk pada pengawasan pengadilan dan berusaha secara maksimal untuk bekerjasama dengan pengadilan asing).

b. The (insert the title of a person or body administering a reorganization or liquidation under the law of the enacting State) is entitled, in the exercise of its functions and subject to the supervision of the court, to communicate directly with foreign courts or foreign representatives. ${ }^{25}$ (Kurator/pengurus asing dalam menjalankan fungsinya yang diawasi oleh pengadilan berhak untuk berkomunikasi langsung dengan pengadilan atau perwakilan asing).

Kerjasama yang dimaksud dalam Pasal 26 tersebut dapat dilaksanakan dengan bentuk sebagai berikut:

a. Penunjukan pihak untuk bertindak atas nama pengadilan (kura-

24 Chapter IV article 26 paragraph 1 and 2 UNCITRAL Model Law on Cross-Border Insolvency with Guide to Enactment.

25 Chapter IV article 26 paragraph 1 and 2 UNCITRAL Model Law on Cross-Border Insolvency with Guide to Enactment. 
tor dan hakim pengawas).

b. Komunikasi terkait informasi yang dianggap penting oleh pengadilan.

c. Koordinasi terkait administrasi dan pengawasan aset dan kepentingan kreditor lainnya.

d. Koordinasi dalam proses persetujuan dan pelaksanaan oleh pengadilan terkait proses persidangan.

e. Negara yang bersangkutan dapat menambah poin kerjasama atas kesepakatan bersama. ${ }^{26}$

Model law ini juga memberi panduan terhadap kasus di mana kreditor tunduk pada prosesi pengadilan nasional dan asing di saat yang bersamaan. Dalam keadaan seperti ini kedua pengadilan tersebut harus melakukan koordinasi aktif yang sesuai. Prinsip yang tercantum pada Bab V Pasal 29 adalah bahwa dimulainya proses pengadilan lokal tidak mencegah atau menghentikan proses pengadilan pailit asing, namun proses kepailitan nasional diberi status prioritas.

Koordinasi pengadilan antar negara ini dilakukan dengan aturanaturan sebagai berikut:

a. Segala macam bentuk bantuan kerjasama harus disesuaikan dan tidak mengganggu jalannya proses pengadilan pailit lokal.

b. Jika kemudian bantuan kerjasama seperti tersebut di atas mengganggu jalannya proses pengadilan pailit lokal, maka bantuan harus ditinjau, dimodifikasi atau dihentikan untuk menjaga eksistensi prosesi pengadilan pailit nasional. ${ }^{27}$

\section{Eksekusi Aset Pailit}

Setelah diakuinya prosesi dan putusan pailit pengadilan asing serta terjalinnya koordinasi antar pengadilan lintas negara, maka tahap selanjutnya adalah eksekusi terhadap aset yang berada di luar yurisdiksi suatu negara. Dalam pelaksanaannya Model Law menjelaskan mekanisme eksekusi aset pailit sebagai berikut:

26 Chapter IV article 27 UNCITRAL Model Law on Cross-Border Insolvency with Guide to Enactment.

27 Chapter IV article 27 UNCITRAL Model Law on Cross-Border Insolvency with Guide to Enactment. 
a. Pada Bab V Pasal 31 UNCITRAL Model Law disebutkan, "In the absence of evidence to the contrary, recognition of a foreign main proceeding is, for the purpose of commencing a proceeding under (identify laws of the enacting State relating to insolvency), proof that the debtor is insolvent." Dijelaskan bahwa putusan pailit pengadilan utama asing dapat dijadikan bukti bahwa kreditor dalam keadaan pailit. Hal ini bertujuan agar pengadilan memiliki landasan hukum yang kuat untuk dapat melaksanakan atau melanjutkan proses kepailitan, termasuk melakukan eksekusi terhadap aset-aset kreditor yang dinyatakan pailit oleh pengadilan asing. Proses ini melibatkan perwakilan atau kurator asing yang bekerja dalam pengawasan pengadilan utama. ${ }^{28}$

b. Pihak yang diberi wewenang oleh pengadilan (kurator/pengurus) untuk melakukan reorganisasi atau likuidasi terhadap aset pailit diberikan kewenangan untuk bertindak di negara asing atas nama pengadilan sesuai dengan hukum yang berlaku di negara tersebut. ${ }^{29}$

Untuk menyelesaikan permasalahan kepailitan lintas batas, khususnya dalam hal eksekusi aset yang berada di luar negeri, Model Law memberi ruang bagi perwakilan asing (kurator) dari luar negeri di mana aset debitor berada untuk melakukan tugasnya. Hal ini dijelaskan pada Bab II pasal 12, "Upon recognition of a foreign proceeding, the foreign representative is entitled to participate in a proceeding regarding the debtor under (identify laws of the enacting State relating to insolvency." 30 Pasal ini menjelaskan bahwa setelah proses kepailitan asing diakui, perwakilan asing (kurator) berhak untuk berpartisipasi dalam proses kepailitan, termasuk dalam hal eksekusi aset pailit. Sehingga kurator asing tersebut akan diberi status prosedural atau legitimasi untuk membuat permohonan, mengenai hal-hal seperti perlindungan, realisasi dan pendistribusian aset debitor, serta kerjasama dengan pihak

28 Chapter V article 31 UNCITRAL Model Law on Cross-Border Insolvency with Guide to Enactment.

29 Chapter I article 5 UNCITRAL Model Law on Cross-Border Insolvency with Guide to Enactment.

30 Chapter II article 12 UNCITRAL Model Law on Cross-Border Insolvency with Guide to Enactment. 
asing.

Untuk memberikan kepastian terhadap status hukum bagi para kreditor, Model Law juga menjamin semua kreditor asing dan lokal memiliki hak yang sama mengenai permulaan dan partisipasi dalam proses kepailitan. Hal ini diatur dalam Bab II Pasal 13 ayat (1) "Subject to paragraph 2 of this article, foreign creditors have the same rights regarding the commencement of, and participation in, a proceeding under (identify laws of the enacting State relating to insolvency) as creditors in this State." 31

Untuk mengatasi perbedaan tafsiran dan atau peringkat khusus kreditor yang diatur dalam undang-undang nasional setiap negara, maka dalam ayat 2 dijelaskan bahwa pasal ini tidak mempengaruhi peringkat klaim (separatis, preferen, konkruen) yang sudah ada dalam perangkat hukum nasional. Kecuali, jika dalam ketentuan tersebut kreditor asing dinilai lebih rendah dari kreditor lokal. "Paragraph 1 of this article does not affect the ranking of claims in a proceeding under (identify laws of the enacting State relating to insolvency), except that the claims of foreign creditors shall not be ranked lower than (identify the class of general non-preference claims, while providing that a foreign claim is to be ranked lower than the general non-preference claims if an equivalent local claim (e.g. claim for a penalty or deferred-payment claim) has a rank lower than the general non-preference claims. ${ }^{32}$ Ayat ini memberikan penegasan bahwa setiap kreditor asing maupun lokal memiliki kedudukan yang sama sesuai dengan statusnya masing-masing.

Menurut Model Law, dalam proses kepailitan lintas batas akan ada dua pengadilan yang terlibat dalam proses kepailitan, yaitu pengadilan dalam negeri dan pengadilan asing dimana aset debitor berada. Hubungan koordinasi yang dilakukan antar dua pengadilan ini dilakukan baik secara langsung maupun melalui perwakilan (kurator) yang diberi kewenangan dan diawasi oleh pengadilan itu sendiri. In matters referred to in article 1, the court shall cooperate to the maximum

31 Chapter II article 13 paragraph 1 UNCITRAL Model Law on Cross-Border Insolvency with Guide to Enactment.

32 Chapter II article 13 paragraph 2 UNCITRAL Model Law on Cross-Border Insolvency with Guide to Enactment. 
extent possible with foreign courts or foreign representatives, either directly or through a (insert the title of a person or body administering a reorganization or liquidation under the law of the enacting State. ${ }^{33}$

Cross-Border Insolvency tidak hanya terjadi di Indonesia namun juga di negara Asia lainnya. Setelah krisis keuangan yang mengakibatkan banyaknya pailit lintas batas, banyak dari negara-negara Asia melakukan reformasi atas peraturan kepailitannya. Sebagai contoh, reformasi tersebut terjadi antara Singapura dan Malaysia yang membuat perjanjian bilateral terkait kepailitan lintas batas, Mutual Recognition and Mutual Enforcement of Republic of Singapore and Malaysia. Saat ini kedua negaara tersebut menjadi yang terdepan di antara negara-negara anggota ASEAN lainnya dalam upaya modernisasi dan harmonisasi hukum kepailitan untuk menghadapi integrasi ekonomi dunia. $^{34}$

Negara anggota ASEAN lain yang sedang mereformasi hukum kepailitannya terkait kepailitan lintas batas adalah Thailand. Sadar akan kebutuhan dalam menghadapi transaksi bisnis internasional, pemerintah Thailand telah memulai dalam mengambil langkah dalam mereformasi peraturan hukum kepailitannya dengan bergabung dalam International Association of Insolvency Regulators (IAIR). Kelompok penyusun rancangan undang-undang tersebut yang diwakili oleh perwakilan dari kementerian hukumnya dalam menghadiri Working Group on Insolvency Law yang diselenggarakan oleh UNCITRAL untuk menyusun instrumen hukum mengenai kepailitan lintas batas. Hingga sekarang kelompok tersebut masih menyiapkan suatu peraturan kepailitan lintas batas yang disesuaikan dengan UNCITRAL. Berdasarkan laporan IAIR pun Thailand belum dapat mengadakan pengakuan terhadap proses kepailitan dan pengurus asing baik secara resiprositas maupun tidak. ${ }^{35}$

Saat ini ada beberapa instrumen hukum internasional yang ada dalam rangka mempermudah proses kepailitan lintas batas yang

33 Chapter IV article 25 UNCITRAL Model Law on Cross-Border Insolvency with Guide to Enactment.

34 Hardjaloka, "Kepailitan Lintas Batas", hlm. 482.

35 Hardjaloka, "Kepailitan Lintas Batas”, hlm. 499-500. 
salah satunya adalah UNCITRAL Model Law On Cross-Border Insolvency with Guide to Enactment dan belum diadopsi dan diratifikasi oleh Indonesia. Berbeda dengan Malaysia dan Singapura yang melakukan perjanjian bilateral serta negara-negara anggota yang membuat perjanjian multilateral bersifat regional supaya putusan pailit dapat diakui di negara anggota perjanjian. ${ }^{36}$

Setelah melihat melihat perkembangan hukum kepailitan negara anggota ASEAN di atas, tentunya Indonesia harus segera bergerak ke arah demikian. Malaysia dan Singapura telah dapat mengatasi permasalahan kepailitan lintas batas antara kedua negara tersebut dengan membuat perjanjian bilateral yang secara substansi sama dengan apa yang ditawarkan oleh UNCITRAL Model Law on Cross Border Insolvency with Guide to Enactmet. Begitu pula dengan Thailand yang sudah menjalin kerjasama dengan UNCITRAL dalam proses modernisasi hukum kepailitannya.

Dengan Model Law yang bersifat fleksibel, UNCITRAL menawarkan mekanisme penyelesaian kepailitan lintas batas yang dapat dimodifikasi sesuai dengan kebutuhan negara-negara yang bersangkutan. Bagi negara-negara penganut asas teritorialisme, Model Law akan sangat membantu Indonesia untuk mengakui dan mengeksekusi putusan pailit pengadilan asing, dan begitupula sebaliknya demi menjaga hak dan kewajiban para pihak.

\section{Kebutuhan Perubahan UU Kepailitan dalam Rangka Mengadopsi UNCITRAL Law on Cross-Border Insolvency with Guide to Enactment}

Perkembangan hukum di Indonesia selama ini diibaratkan berjalan tertatih-tatih di belakang perkembangan ekonomi yang sangat pesat. Ini merupakan konsekuensi logis dari strategi pembangunan yang lebih menitikberatkan pada bidang ekonomi sehingga mengalami kemajuan yang pesat. Sementara pembangunan di bidang hukum nyaris terkesampingkan, sehingga perkembangannya sangat lamban. Akibatnya sering terjadi kesenjangan, banyak tatanan hukum positif

36 Hardjaloka, "Kepailitan Lintas Batas”, hlm. 502. 
yang tidak sesuai lagi dengan dinamika kehidupan masyarakat. ${ }^{37}$

Untuk memperbarui hukum kepailitan Indonesia agar dapat mengakomodir permasalahan kepailitan lintas batas, Indonesia perlu melakukan beberapa perubahan terhadap hukum kepailitannya. Untuk itu penulis akan menjabarkan sebagian dari beberapa penyesuaian yang harus dilakukan untuk mengadopsi UNCITRAL Model Law on Cross-Border Insolvency with Guide to Enactment di Indonesia, yaitu:

\section{Asas teritorialitas Indonesia}

Berbagai studi tentang hubungan hukum dan pembangunan ekonomi menunjukkan bahwa pembangunan ekonomi tidak akan berhasil tanpa pembaruan hukum, Dengan terhambatnya investasi akibat dari tidak adanya kepastian hukum dan tidak adanya perlindungan yang seimbang antara debitor, kreditor dan pihak yang berkepentingan akan mengancam stabilitas pembangunan perekonomian secara keseluruhan. ${ }^{38}$ Berbicara tentang putusan pailit yang diputus oleh pengadilan asing yang akan dieksekusi di suatu negara, pada prinsipnya akan terkait dengan pertanyaan apakah putusan pengadilan asing dapat dieksekusi di suatu negara. Secara umum dapat dikatakan bahwa kebanyakan sistem hukum yang dianut oleh banyak negara tidak memperkenankan pengadilannya untuk mengeksekusi putusan pengadilan asing. Kecenderungan ini tidak saja berlaku pada negara-negara yang menganut sistem Civil Law tetapi berlaku juga bagi negara-negara yang menganut sistem Common Law. Penolakan eksekusi terhadap putusan pengadilan asing terkait erat dengan konsep kedaulatan Negara. ${ }^{39}$ Maksud dari asas ini adalah untuk menjaga kedaulatan suatu negara. Namun demikian, asas teritorialitas ini dapat diterobos melalui hubungan baik berdasarkan prinsip resiprosi-

37 Riduan Syahrani, Seluk Beluk dan Asas-asas Hukum Perdata (Jakarta: PT. Alumni, 2013), hlm. 296.

38 Hervana Wahyu Prihatmaka, Sunarmi, dan Rahmad Hendra, "Insolvensi dalam Hukum Kepailitan di Indonesia (Studi Putusan No. 48/Pailit/2012/ Pn.Niaga.Jkt.Pst antara PT. Telekomunikasi Selular Vs PT. Primajaya Informatika)", Fiat Justicia, 8, 2 (2014), hlm. 335.

39 Dasril Adnin, "Aspek-aspek Internasional dalam Hukum Kepailitan”, Jurnal Sains dan Inovasi, 6, 1 (2010), hlm. 71. 
tas atau hubungan timbal balik. Saat ini Indonesia memang sudah mempunyai regulasi mengenai bantuan hukum timbal balik dalam hukum pidana (mutual legas assistant in criminal metters), yang diatur dalam Undang-Undang Nomor 1 Tahun 2006 tentang Bantuan Hukum Timbal balik dalam Masalah Pidana, tetapi dalam masalah perdata, termasuk kepailitan belum ada regulasinya. ${ }^{40}$

Seharusnya prinsip resiprositas atau timbal balik ini juga diberlakukan dalam hukum perdata Indonesia. Sama halnya dengan kerjasama timbal balik dalam hukum pidana di atas, hukum perdata khususnya kepailitan lintas batas juga membutuhkan sebuah undang-undang yang dapat menjadi landasan hukum bagi penerapan UNCITRAL Model Law on Cross-Border Insolvency with Guide to Enactment. UNCITRAL pun tidak mewajibkan negara yang akan mengadopsi Model Law untuk meminta persetujaun atau mengajukan permohonan dan dapat memodifikasi Model Law ini sesuai kebutuhan negaranya. Hal ini tentunya mempermudah Indonesia untuk segera melakukan kajian terhadap UNCITRAL Model Law on Cross-Border Insolvency with Guide to Enactment dan melakukan modifikasi sesuai dengan hukum nasional yang berlaku agar tidak terjadi tumpang tindih atau benturan antar produk hukum.

Dalam hal ini Indonesia harus segera membuat undang-undang tentang bantuan hukum timbal balik dalam hal keperdataan, khususnya kepailitan. Hal ini bertujuan untuk menjadi ketentuan hukum pendukung bagi proses harmonisasi hukum kepailitan dengan negara lain. Jika undang-undang ini dapat diwujudkan, maka usaha Indonesia untuk melakukan upgrade terhadap hukum kepailitan dengan negara-negara anggota ASEAN lainnya akan lebih mudah.

\section{Hukum Kepailitan Indonesia}

Proses kepailitan Indonesia dalam UU Kepailitan yang berlaku sekarang belum mengatur mengenai mekanisme ataupun prosedur kepailitan lintas batas. Tiga pasal yang mengatur tentang hal tersebut hanya berkaitan dengan pemindahan benda yang termasuk dalam

40 Sinaga, Hukum Kepailitan Indonesia, hlm. 174-175. 
harta pailit di luar negeri dan pemindahan sebagian atau seluruh utang atau piutang ke pihak ketiga. Pasal 3 UU ini yang membahas tentang kompetensi relatif dari pengadilan yang berwenang untuk mengadili proses kepailitan juga tidak cukup mengakomodir unsur lintas batas di dalamnya. Keseluruhan penjelasan dalam pasal ini hanya menjadikan debitor yang melakukan profesi atau usahanya di wilayah RI. ${ }^{41}$

Pada tahapan ini, menurut penulis harus dilakukan revisi terhadap UU Kepailitan Indonesia dalam rangka modernisasi dan harmonisasi UU kepailitan negara-negara anggota ASEAN. Indonesia setidaknya dapat mengadopsi beberapa pasal yang ada di dalam UNCITRAL Model Law, antara lain:

a. Menambahkan unsur internasional dalam Bab I Pasal 1 tentang Ketentuan Umum seperti "foreign main proceeding" atau proses persidangan utama asing dan "foreign proceeding" atau prosesi asing seperti yang dijelaskan dalam Pasal 2 UNCITRAL Model Law.

b. Menambahkan ketentuan tentang persyaratan pengakuan proses dan perwakilan (kurator) asing yang dijelaskan dalam Pasal 15 UNCITRAL Model Law. Dapat dibuatkan Bab baru dalam UU Kepailitan yang khusus membahas proses ini.

c. Bab ke X UU Kepailitan tentang Ketentuan-ketentuan Hukum Internasioanl sebaiknya ditambahkan pasal yang menjelaskan tentang kerjasama pengadilan Indonesia dengan pengadilan dan atau perwakilan(kurator asing). Pasal 25, 26 dan 27 UNCITRAL Model Law dapat dijadikan rujukan untuk perumusan ketentuan ini. Pasal-pasal diatas menjelaskan dengan rinci bagaimana pangadilan melakukan koordinasi dengan pengadilan negara lain dan perwakilan (kurator) asing melaksanakan eksekusi terhadap aset debitor pailit di suatu negara dengan pengawasan pengadilan setempat.

Hukum kepailitan Indonesia sudah cukup rinci dalam mengatur eksekusi aset debitor pailit. Pasal 21 UU Kepailitan saat ini mengikat seluruh aset debitor pailit yang berada dalam wilayah Indonesia mau-

41 Pasal 3 UU Kepailitan. 
pun yang berada di luar negeri. Namun di sisi lain, ada asas teritorialitas yang kemudian menghambat eksekusi terhadap putusan pailit tersebut dan hal itu juga berlaku di Indonesia. Untuk itu perlu penambahan ketentuan dalam UU Kepailitan terkait eksekusi aset yang berada di luar wilayah Indonesia, seperti yang diatur pada pasal 12,13, 25, 31 Model Law. Sekiranya dapat dirumuskan pasal baru dalam UU Kepailitan yang mengatur tentang mekanisme kerja perwakilan (kurator) asing dan pengawasannya saat melakukan eksekusi putusan pailit asing di Indonesia. Hal ini juga harus diterapkan di negara lain, sehingga peraturan hukum kepailitan lintas batas dapat saling mengakui dan mendukung proses eksekusi aset debitor pailit.

Prinsip fleksibel Model Law yang diatur dalam Pasal 11 dan 12 Guide to Enactment membuat semua kemungkinan perubahan terhadap Model Law ini sesuai dengan kebutuhan ASEAN sangat terbuka. ASEAN dapat menampung segala macam aspirasi dan kepentingan seluruh negara-negara anggotanya dalam perumusan perjanjian dan ratifikasi peraturan kepailitan lintas batas ASEAN. Terbentuknya peraturan hukum terkait kepailitan lintas batas di ASEAN yang modern dan harmonis akan menjadi penggerak utama dalam mengawal kegiatan perekonomian antar negara-negara dalam lingkup ASEAN.

\section{Kesimpulan}

Dalam rangka modernisasi dan harmonisasi hukum kepailitan dunia, UNCITRAL Model Law on Cross Border Insolvency with Giude to Enactment sangat dapat membantu negara-negara anggota ASEAN dalam usaha membangun komitmen, merancang produk hukum hingga menyepakati hukum kepailitan lintas batas dalam rangka mengahadapi integrasi ekonomi dunia, khususnya wilayah ASEAN. Setelah melakukan analisis terhadap UNCITRAL Model Law, penulis menyimpulkan bahwa Model Law dapat diadopsi oleh Indonesia dalam menghadapai integrasi ekonomi ASEAN. UU Kepailitan yang berlaku saat ini hanya memiliki tiga pasal yang mengatur aspek internasional di dalamnya, yaitu pada Pasal 212, 213 dan 214. Ketiga pasal tersebut hanyalah berkaitan dengan pemindahan benda yang termasuk 
dalam harta pailit di luar negeri dan pemindahan sebagian atau seluruh utang atau piutang ke pihak ketiga. UU ini tidak mengatur bagaimana mekanisme dan prosedur eksekusi jika aset tersebut berada di luar negeri, kejasama pengadilan lintas negara, danpengakuan putusan pailit pengadilan asing.

Asas fleksibilitas yang dianut oleh UNCITRAL Model Law akan memudahkan Indonesia dalam upaya modifikasi UU Kepailitan. Model Law ini juga telah secara konkrit memberikan acuan terkait hal-hal yang perlu diatur untuk penyelesaian sengketa kepailitan lintas batas. Bab I Pasal 1 tentang Ketentuan Umum seperti "foreign main proceeding", Pasal 15 UNCITRAL Model Law tentang pengakuan proses dan perwakilanasing, serta Pasal 25, 26 dan 27 UNCITRAL Model Law tentang kerjasama pengadilan dengan perwakilan dan pengadilan asing akan membantu langkah awal Indonesia untuk merumuskan hukum kepailitan nasional yang modern dan harmonis. Indonesia harus mampu beradaptasi dengan baik namun juga tetap menjaga kepentingan nasional dalam menghadapi integrasi ekonomi ASEAN yang berkembang pesat dan begitu dinamis.

\section{Daftar Pustaka}

\section{Artikel/Buku}

Adnin, Dasril. "Aspek-Aspek Internasional dalam Hukum Kepailitan”. Jurnal Sains dan Inovasi, 6, 1 (2010): 69-75.

Anisah, Siti. Perlindungan Kepentingan Kreditor dan Debitor dalam Hukum Kepailitan Indonesia. Yogyakarta: Total Media, 2008.

Dewi, Ni Putu Agustini Ari dan A.A. Ngr Yusadarmadi. "Peran Peradilan Niaga Sebagai Lembaga Penyelesaian Perkara Kepailitan”. Kertha Semaya, 1, 5 (2013): 1-5.

Hardjaloka, Laura. "Kepailitan Lintas Batas: Perspektif Hukum Internasional dan Perbandingannya dengan Instrumen Nasional di Beberapa Negara”. Yuridika, 30, 3 (2015): 480-504. DOI: 10.20473/ydk.v30i3.1952

Http: / / www.uncitral.org/uncitral/en/about_us.html, diakses $22 / 10 / 2017$. 
Jamtomo, Rahardjo. Sub Wilayah Ekonomi ASEAN dan Kawasan Perdagangan Bebas (AFTA). Jakarta: Sekretariat Nasional ASEAN Departemen Luar Negeri, 1996.

Jono. Hukum Kepailitan. Jakarta: Sinar Grafika, 2010.

Josep, Freddy. "Perlukah Revisi Undang-Undang Kepailitan? (Suatu Kajian Mengenai Imbas Kasus Manulife dan Prudential). Jurnal Hukum dan Pembangunan, 34, 1 (2004): 66-78. DOI: 10.21143/jhp. vol34.no1.1427

Juwana, Hikmahanto. “Transaksi Bisnis Internasional dalam Kaitannya dengan Peradilan Niaga”. Jurnal Hukum dan Pembangunan, 31, 3 (2001): 224-227. DOI: 10.21143/jhp.vol31.no3.1303

Luhulima, C.P.F. Seperempat Abad ASEAN. Jakarta: Proyek Kerjasama Antar Negara ASEAN, Sekretariat Nasional ASEAN, Departemen Luar Negeri, 1994.

Muldani, A. Riris. "Pertimbangan Hakim yang Tidak Menerima Permohonan Pailit terhadap Perusahaan Multinasional di Indonesia (Analisis Putusan Nomor 30/Pailit/2002/PN.Niaga/Jkt.Pst". Skripsi, UIN Sunan Kalijaga, Yogyakarta, 2016.

Prihatmaka, Hervana Wahyu, Sunarmi, dan Rahmad Hendra. "Insolvensi dalam Hukum Kepailitan di Indonesia (Studi Putusan No. 48/Pailit/2012 / Pn.Niaga.Jkt.Pst antara PT. Telekomunikasi Selular Vs PT. Primajaya Informatika)”. Fiat Justicia, 8, 2 (2014): 326-341. DOI: 10.25041 / fiatjustisia.v8no2.295

Simanjuntak, Ricardo. "Digagas Aturan Cross-Border Insolvency". http:/ / www.hukumonline.com/berita/baca/lt51f366e338725/ digagas--aturan-icross-border-insolvency-i, 27/07/2017. Diakses $22 / 10 / 2017$.

Sinaga, Syamsudin M. Hukum Kepailitan Indonesia. Jakarta: Tatanusa, 2012.

Sjahdeini, Sutan Remy. Hukum Kepailitan. Jakarta: Pustaka Utama Grafiti, 2002.

Sujatmiko, Bagus dan Nyulistiowati Suryanti. "Perlindungan Hukum bagi Investor pada Perusahaan Terbuka yang Dinyatakan Pailit Ditinjau dari Hukum Kepailitan”. Bina Mulia Hukum, 2, 1 (2017):

15-25. DOI: $10.23920 /$ jbmh.v2n1.2 
Syahrani, Riduan. Seluk Beluk dan Asas-asas Hukum Perdata. Jakarta: PT. Alumni, 2013.

\section{Peraturan Perundang-undangan dan Putusan Pengadilan}

Republik Indonesia. Undang-undang Nomor 37 Tahun 2004 tentang Kepailitan dan Penundaan Kewajiban Pembayaran Utang. Pengadilan Negeri Jakarta Pusat. Putusan Pengadilan Niaga Nomor 30/Pailit/2002 / PN.Niaga/Jkt/Pst.

United Nations Commission on International Trade Law. UNCITRAL Model Law on Cross-Border Insolvency with Guide to Enactment (1997). 